\title{
Synthesis of Unsymmetrical Triarylamines for Photonic Applications via One-Pot Palladium-Catalyzed Aminations
}

\author{
S. Thayumanavan, ${ }^{\dagger}$ Stephen Barlow, ${ }^{\dagger}$ and Seth R. Marder*,t, \\ Beckman Institute, 139-74 California Institute of Technol ogy, Pasadena, California 91125, \\ and J et Propulsion Laboratory, 139-74 California Institute of Technology, \\ Pasadena, California 91125
}

Received August 13, $1997^{\otimes}$

\begin{abstract}
Syntheses of unsymmetrically substituted triarylamines have been achieved by a one-pot procedure using $\mathrm{C}-\mathrm{N}$ bond-forming reactions, where two aryl bromides are sequentially added to an arylamine in the presence of a palladium catalyst. This methodology has been utilized to synthesize a number of substituted analogs of 4,4'-bis(m-tolylphenylamino)biphenyl, which may be useful as the hole transport component of vapor-deposited organic light-emitting diodes. The variations in the substitution are anticipated to lead to a variety of band gaps, band offsets, and glass transition temperatures in this class of materials.
\end{abstract}

\section{Introduction}

Organic materials for information transfer using photonic and el ectronic technology have been of intense interest due to the commercial and technological implications. ${ }^{1}$ Triarylamine derivatives have attracted considerable attention as components of these materials. It has been recognized that triarylamine-derived secondorder nonlinear optical (NLO) chromophores and other dyes are more stable, both thermally and photochemically, in comparison to their alkyl counterparts. ${ }^{2}$ We have recently demonstrated that organic chromophores with very high nonlinearities can be synthesized using triarylamine-based chromophores. ${ }^{3}$ In addition, triarylamine derivatives, such as 4,4'-bis(m-tolyl phenylamino)bi phenyl (TPD) and 1,1-bis(4-(di-p-tolylamino)phenyl)cyclohexane (TAPC), also serve as hole transport materials for applications in xerography ${ }^{4}$ and in vapordeposited organic light-emitting diodes (OLEDs). ${ }^{5}$ Copper-catalyzed UIImann type reactions have been used extensively to synthesize triarylamine compounds. ${ }^{6}$ However, the harsh conditions and inconsistent yields of these reactions have severely limited chemists from

\footnotetext{
† Beckman Institute.

₹ et Propulsion Laboratory.

ه Abstract published in Advance ACS Abstracts, October 15, 1997.

(1) (1) Pol ymers for Light Wave and Integrated Optics; Hornak, L. A., Ed.; Marcel Dekker: New York, 1992.

(2) Moylan, C. R.; Twieg, R. J .; Lee, V. Y.; Swanson, S. A. Betterton, K. M.; Miller, R. D. J . Am. Chem. Soc. 1993, 115, 12599.

(3) J en, A. K. Y.; Cai, Y. M.; Bedworth, P. V.; Marder, S. R. Adv. Mater. 1997, 9, 132.

(4) (a) Borsenberger, P. M.; Gruenbaum, W. T.; Magin, E. H. Physica B 1996, 228, 226. (b) Borsenberger, P. M.; O'Regan, M. B. Chem. Phys. 1995, 200, 257

(5) (a) Mori, T.; Obata, K.; Imaizumi, K.; Mizutani, T. Appl. Phys. Lett. 1996, 69, 3309. (b) J ordan, R. H.; Rothberg, L. J.; Dodabalapur, A.; Slusher, R. E. Appl. Phys. Lett. 1996, 69, 1997. (c) Kalinowski, J .; Dimarco, P.; Cocchi, M.; Fattori, V.; Camaioni, N.; Duff, J . Appl. Phys. Lett. 1996, 68, 2317. (d) Burrows, P. E.; Shen, Z.; Bulovic, V.; McCarty, D. M.; Forrest, S. R.; Cronin, J. A.; Thompson, M. E. J . Appl. Phys. 1996, 79, 7991. (e) VanSlyke, S. A.; Chen, C. H.; Tang, C. W. Appl. Phys. Lett. 1996, 69, 2160. (f) Tang, C. W.; VanSlyke, S. A. Appl. Phys. Lett. 1987, 51, 913.
}

(6) (a) Bedworth, P. V.; Cai, Y. M.; J en, A. K. Y; Marder, S. R. J . Org. Chem. 1996, 61, 2242. (b) Gauthier, S.; Fréchet, J . M. J . Synthesis 1987, 383. synthesizing highly functionalized molecules using this methodology. Recently, there has been significant progress in the development of aromatic amination reactions utilizing milder conditions. Following Migita's seminal work on palladium-catalyzed $\mathrm{C}-\mathrm{N}$ bond-forming reactions of aryl bromides and aminostannanes, modified conditions have been developed to effect a mild and efficient route for synthesis of arylamines. ${ }^{7}$ In this paper, we describe a high-yielding one-pot synthetic procedure to obtain unsymmetrically substituted triarylamines using the palladium-catalyzed amination reaction. The utility of this strategy has also been demonstrated by the synthesis of several analogs of TPD.

\section{Results and Discussion}

In view of our continuing interest in the synthesis of stable, soluble, and functionalized chromophores for second-order nonlinear optical materials, we synthesized 4,4'-dibutyltriphenylamine (3) in $84 \%$ yield from aniline (1) and two equival ents of 1-bromo-4-butylbenzene (2) in one pot using the palladium-catalyzed amination reaction as shown in Scheme 1 . The reaction was carried out in toluene at $90{ }^{\circ} \mathrm{C}$ using $2.0 \mathrm{~mol} \%$ of tris(dibenzylideneacetone)dipalladium $\left(\mathrm{Pd}_{2}(\mathrm{dba})_{3}\right), 3.0$ mol \% of 1,1'-bis(diphenyl phosphino)ferrocene (DPPF), and 2.5 equiv of sodium tert-butoxide.

While monitoring the above reaction for completion by TLC, we noticed that the triarylamine product appeared only after the completion of the formation of the diarylamine. This led us to consider the possibility of synthesizing unsymmetrical triarylamines in one pot by the sequential addition of two different aryl bromides. Accordingly, when aniline (1) was treated with 1 equiv of aryl bromide 4 in the presence of $0.6 \mathrm{~mol} \%$

(7) (a) Kosugi, M.; Kameyama, M.; Migita, T. Chem. Lett. 1983, 927. (b) Marcoux, J . F.; Wagaw, S.; Buchwald, S. L. J . Org. Chem. 1997, 62, 1568. (c) Wolfe, J . P.; Wagaw, S.; Buchwald, S. L. J . Am. Chem Soc. 1996, 118, 7215 and references cited therein. (d) Louie, J.; Hartwig, J . F. Angew. Chem., Int. Ed. Engl. 1996, 35, 2359. (e) Driver, M. S.; Hartwig, J . F.J . Am. Chem. Soc. 1996, 118, 7217 and references cited therein. (f) Hartwig, J . F. Synlett, 1997, 329. 
Scheme 1

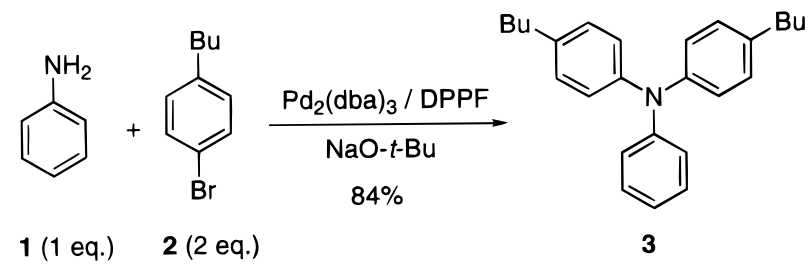

Scheme 2

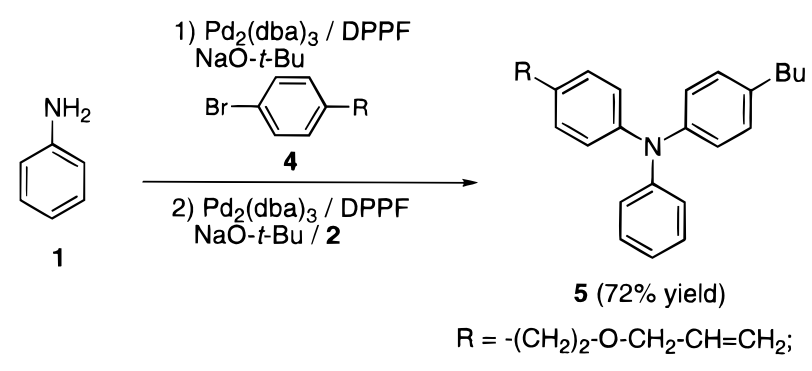

of $\mathrm{Pd}_{2}(\mathrm{dba})_{3}$ and $0.9 \mathrm{~mol} \%$ of DPPF, the starting materials disappeared after a few hours. At this juncture, the second aryl bromide $\mathbf{2}$ and sodium tertbutoxide were added along with additional catalyst mixture (1.2 mol \% of $\mathrm{Pd}_{2}(\mathrm{dba})_{3}$ and $1.8 \mathrm{~mol} \%$ of DPPF ). After $18 \mathrm{~h}$, purification of the reaction mixture afforded the unsymmetrical triarylamine 5 in $72 \%$ yield (Scheme 2). When compound $\mathbf{5}$ was synthesized in a stepwise manner from $\mathbf{1}, \mathbf{4}$, and $\mathbf{2}$, the overall yield of the reaction over two steps was $61 \%$.

We are also interested in triarylamines as components of vapor-deposited LEDs. ${ }^{5}$ In particular, we are interested in investigating the effects of electron-withdrawing and electron-donating groups on the terminal aromatic ring of the TPD-like structures. Here we report that our one-pot synthesis of unsymmetrical triarylamines provides a facile access to a series of TPD analogs, which may provide us with a structureproperty relationship model for this class of organic materials.

Compounds $10 \mathbf{a}-10 \mathrm{k}$ were synthesized from commercially available arylamines and aryl bromides. Treatment of the arylamine 6 with 4,4'-dibromobiphenyl (7) in toluene at $90{ }^{\circ} \mathrm{C}$ in the presence of $1.5 \mathrm{~mol} \% \mathrm{Pd}_{2}-$ $(\mathrm{dba})_{3}, 2.3 \mathrm{~mol} \%$ DPPF, and 1.3 equiv of sodium tertbutoxide provided 4,4'-diarylaminobi phenyl 8 as judged by TLC. ${ }^{8}$ After the complete disappearance of the starting arylamine 6, the second aryl bromide 9 was added along with sodium tert-butoxide to afford the product $\mathbf{1 0}$ in moderate to excellent yields as depicted in Scheme 3 and Table 1.

When the synthesis of 10a was carried out by a stepwise procedure, the overall yield of the reaction was $62 \%$ in comparison with the $82 \%$ yield obtained by the one-pot protocol. When m-toluidine was treated with p-fluorobromobenzene followed by the addition of 4,4'dibromobiphenyl (7) as the second aryl bromide, the

(8) The formation of $\mathbf{8}$ was judged by the disappearance of the arylamine 6 . The compound 4,4'-bis(m-tolylamino)biphenyl has also been synthesized independently and was cospotted with appropriate reaction mixtures and starting materials to judge the completion of the first step of the reaction.

(9) In the general methodology depicted in Scheme 3, the second aryl bromide can be added in excess. However, in the alternate pathway the second aryl bromide 7 should be exactly 0.5 equiv relative to the arylamine to achieve optimal yields.

\section{Scheme 3}

$$
\mathrm{Ar}^{1}-\mathrm{NH}_{2} \frac{\begin{array}{l}
\text { 1) } \mathrm{Pd}_{2}(\mathrm{dba})_{3} / \mathrm{dppt} \\
\mathrm{NaO}-t-\mathrm{Bu} / 7
\end{array}}{\text { 2) } \mathrm{Ar}{ }^{2}-\mathrm{Br}(9)}
$$

6

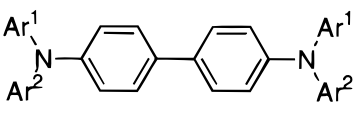

10 product $\mathbf{1 0 b}$ is obtained in only $41 \%$ yield. This yield was much poorer when compared to the $85 \%$ yield obtained when 7 was used as the first aryl bromide. At this juncture, the reason for this difference in yield is unclear. ${ }^{9}$

It is particularly intriguing that aryl bromides 9 with electron-withdrawing substituents (entries 2, 4, 10, and $12)^{10}$ or electron-donating substituents (entry 6 ) at the para position require longer times for the completion of the reaction. While our observation is consistent with previous reports with respect to the electron-donating substituents, it is intriguing that our results with electron-withdrawing groups contradict Hartwig's recent mechanistic studies on reductive eliminations. ${ }^{11,12}$

We have used our methodology to synthesize two naphthyl-based compounds, 10j and 10k, which have much higher glass transition temperatures than the corresponding phenyl analogs. High glass transition temperature is an important factor in achieving more stable LED devices.

\section{Conclusions}

Our ability to optimize the band gap, work function, and the glass transition temperatures of the TPD-type compounds using the current methodology should enable us to fabricate better performing organic LED devices. In summary, we have described a useful strategy for synthesizing multigram quantities of unsymmetrical triarylamines in one pot. In addition to the superior yields of this one-pot methodology, it also precludes the necessity for the purification of the diarylamine intermediate. We have also utilized this strategy to synthesize several analogs of TPD, in which four $\mathrm{C}-\mathrm{N}$ bonds are formed regioselectively by a cataIytic process in one pot. Investigation of the effect of these structural variations on OLED device performance, utilizing the data to understand the structureproperty relationships and thus develop a model to improve on the efficiency of the devices, is currently in progress. We believe that, in addition to our application of this methodology to synthesize molecules for OLEDs and second-order NLO materials, it will be a useful process for other applications.

\section{Experimental Section}

${ }^{1} \mathrm{H}-\mathrm{NMR}$ spectra were recorded on a General Electric QE$300 \mathrm{FT}$ NMR spectrometer using the residual proton resonance of the solvent as the internal standard. Chemical shifts are reported in parts per million (ppm). When peak multiplicities are given, the following abbreviations are used: $s$, singlet; $d$, doublet; $t$, triplet; $q$, quartet; $d$ of $d$, doublet of a doublet; $m$, multiplet; b, broad. ${ }^{13} \mathrm{C}-\mathrm{NMR}$ spectra were proton decoupled and recorded on a QE-300 using the carbon signal of the

(10) It is not clear to us why the cyano substituent at the meta position also inhibits the reaction (entry 9).

(11) Driver, M. S.; Hartwig, J . F. J . Am. Chem. Soc. 1997, 119, 8232 and references therein.

(12) From a synthetic viewpoint, this problem can be circumvented by having the electron-donating functional group on the starting arylamine 6 instead of the aryl bromide 9 (compare entries 6 and 7). 
Table 1. Synthesis of 4,4'-Bis(diarylamino)biphenyls 10 by the One-Pot Method

\begin{tabular}{|c|c|c|c|c|c|c|}
\hline entry & $\mathrm{Ar}^{1-}$ & $\mathrm{Ar}^{2-}$ & reaction time $(\mathrm{h})^{\mathrm{a}}$ & product & isolated yield (\%) & $\mathrm{T}_{\mathrm{g}}\left({ }^{\circ} \mathrm{C}\right)$ \\
\hline 1 & $\mathrm{~m}-\mathrm{Me}-\mathrm{C}_{6} \mathrm{H}_{4}-$ & $\mathrm{m}-\mathrm{F}-\mathrm{C}_{6} \mathrm{H}_{4}-$ & 18 & $10 a$ & 82 & 55 \\
\hline 2 & $\mathrm{~m}-\mathrm{Me}-\mathrm{C}_{6} \mathrm{H}_{4}-$ & $\mathrm{p}-\mathrm{F}-\mathrm{C}_{6} \mathrm{H}_{4}-$ & 40 & 10b & 85 & 58 \\
\hline 3 & $\mathrm{~m}-\mathrm{Me}-\mathrm{C}_{6} \mathrm{H}_{4}-$ & $\mathrm{m}, \mathrm{m}-\mathrm{F}_{2}-\mathrm{C}_{6} \mathrm{H}_{3}-$ & 16 & $10 c$ & 63 & 56 \\
\hline 4 & $\mathrm{~m}-\mathrm{Me}-\mathrm{C}_{6} \mathrm{H}_{4}-$ & $\mathrm{m}, \mathrm{m}, \mathrm{p}-\mathrm{F}_{3}-\mathrm{C}_{6} \mathrm{H}_{2}-$ & 54 & 10d & 55 & 56 \\
\hline 5 & $\mathrm{~m}-\mathrm{Me}-\mathrm{C}_{6} \mathrm{H}_{4}-$ & $\mathrm{m}-\mathrm{OMe}-\mathrm{C}_{6} \mathrm{H}_{4}-$ & 16 & $10 \mathrm{e}$ & 76 & 63 \\
\hline 6 & $\mathrm{~m}-\mathrm{Me}-\mathrm{C}_{6} \mathrm{H}_{4}-$ & $\mathrm{p}-\mathrm{OMe}-\mathrm{C}_{6} \mathrm{H}_{4}-$ & 60 & $10 f$ & $22^{\mathrm{b}}$ & \\
\hline 7 & $\mathrm{p}-\mathrm{OMe}-\mathrm{C}_{6} \mathrm{H}_{4}-$ & $\mathrm{m}-\mathrm{Me}-\mathrm{C}_{6} \mathrm{H}_{4}-$ & 12 & $10 f$ & 90 & 58 \\
\hline 8 & $\mathrm{~m}-\mathrm{Me}-\mathrm{C}_{6} \mathrm{H}_{4}-$ & $\mathrm{m}-\mathrm{CF}_{3}-\mathrm{C}_{6} \mathrm{H}_{4}-$ & 17 & $10 \mathrm{~g}$ & 57 & 47 \\
\hline 9 & $\mathrm{~m}-\mathrm{Me}-\mathrm{C}_{6} \mathrm{H}_{4}-$ & $\mathrm{m}-\mathrm{CN}-\mathrm{C}_{6} \mathrm{H}_{4}-$ & 70 & $10 h$ & 66 & 68 \\
\hline 10 & $\mathrm{~m}-\mathrm{Me}-\mathrm{C}_{6} \mathrm{H}_{4}-$ & $\mathrm{p}-\mathrm{CN}-\mathrm{C}_{6} \mathrm{H}_{4}-$ & 60 & $10 \mathrm{i}$ & 87 & 85 \\
\hline 11 & 1-naph & $\mathrm{m}-\mathrm{Me}-\mathrm{C}_{6} \mathrm{H}_{4}-$ & 18 & 10j & 84 & 101 \\
\hline 12 & 1-naph & $\mathrm{p}-\mathrm{F}-\mathrm{C}_{6} \mathrm{H}_{4}-$ & 54 & $10 \mathrm{k}$ & 64 & 104 \\
\hline
\end{tabular}

a Time taken for the second step of the reaction to be complete. ${ }^{b}$ The yield was estimated by NMR using relative integration of a mixture of inseparable products.

deuterated solvent as the internal standard. Fast atom bombardment (FAB) or electron impact (EI) mass spectra were performed at the University of California, Riverside, or at the Caltech Mass Spectrometry Facility. Elemental analyses were performed by the Atlantic Microlab, Inc. Norcross, Georgia. Flash chromatography was performed with EM science 37$75, \mu \mathrm{m}$ silica gel. Analytical thin layer chromatography was performed on EM Science silica plates with F-254 indicator, and the visualization was accomplished by UV lamp or using the molybdic acid stain mixture. If microanalyses are not reported, the purity of the compounds were judged to be $>90 \%$ by ${ }^{1} \mathrm{H}-\mathrm{NMR}$ and ${ }^{13} \mathrm{C}-\mathrm{NMR}$, and the compound was also further characterized by the high-resolution mass spectrometry. Samples for thermal analysis were recrystalized or reprecipitated from appropriate solvents systems. Thermal data were obtained using a Perkin EImer DSC-7 differential scanning calorimeter. The sample was heated in a sealed pan from 20 to $250{ }^{\circ} \mathrm{C}$ at the rate of $10^{\circ} \mathrm{C} / \mathrm{min}$ to observe the melting point of the sample. The reported melting point $\left(T_{m}\right)$ is the peak of the observed melting transition. This sample was then rapidly cooled back to $20^{\circ} \mathrm{C}$ and then reheated at the rate of $10^{\circ} \mathrm{C} /$ min to observe the glass transition temperature $\left(T_{g}\right)$ of the sample. All the reported yields are isolated yields unless otherwise indicated. Toluene was distilled over $\mathrm{Na} / \mathrm{Ph}_{2} \mathrm{CO}$ ketyl. Aniline and $\mathrm{m}$-toluidine were distilled from $\mathrm{CaH}_{2}$. All the other solvents and reagents were used as obtained from the commercial sources unless otherwise mentioned. Standard workup procedure in the reaction involved cooling the reaction mixture to room temperature and then separating the reaction mixture between ether (and/or toluene) and aqueous layers. The organic layers were collected together and concentrated in vacuo to afford the crude reaction mixture.

Synthesis of 4,4-Dibutyltriphenylamine from 1-Bromo4-butylbenzene and Aniline. To a solution of tris(dibenzylideneacetone)dipalladium $\left(\mathrm{Pd}_{2}(\mathrm{dba})_{3}\right)(0.896 \mathrm{~g}, 0.979 \mathrm{mmol})$ and bis(diphenylphosphino)ferrocene (DPPF) (0.814 g, 1.469 $\mathrm{mmol})$ in toluene $(120 \mathrm{~mL})$ under nitrogen atmosphere was added 1-bromo-4-butylbenzene (20.898 g, $97.889 \mathrm{mmol})$ at room temperature, and the resultant mixture was stirred at that temperature for $10 \mathrm{~min}$. Then, sodium tert-butoxide (10.691 g, $112.0 \mathrm{mmol}$ ) and aniline ( $4.144 \mathrm{~g}, 44.495 \mathrm{mmol})$ were added to this solution and stirred at $90^{\circ} \mathrm{C}$ for $24 \mathrm{~h}$. Following the standard workup procedure, the reaction mixture was purified by flash column chromatography using $3 \%$ ethyl acetate in hexane as the mobile phase to afford $13.32 \mathrm{~g}$ of the product as a yellowish oil. ${ }^{1} \mathrm{H} \mathrm{NMR}\left(\mathrm{CDCl}_{3}, 300 \mathrm{MHz}\right) \delta 7.27$ $(\mathrm{d}, 2 \mathrm{H}, \mathrm{J}=8.2 \mathrm{~Hz}) ; 7.14-6.98(\mathrm{~m}, 11 \mathrm{H}) ; 2.62(\mathrm{t}, 4 \mathrm{H}, \mathrm{J}=7.7$ $\mathrm{Hz}) ; 1.65(\mathrm{~m}, 4 \mathrm{H}) ; 1.45(\mathrm{~m}, 4 \mathrm{H}) ; 1.00(\mathrm{t}, 6 \mathrm{H}, \mathrm{J}=7.2 \mathrm{~Hz}) .{ }^{13} \mathrm{C}$ NMR $\left(\mathrm{CDCl}_{3}, 75 \mathrm{MHz}\right) \delta 148.2,145.5,137.3,129.1,129.0$, 124.3, 123.0, 121.7, 35.0, 33.7, 22.4, 14.0. FAB HRMS calcd for $\mathrm{C}_{26} \mathrm{H}_{32} \mathrm{~N}(\mathrm{M}+\mathrm{H})$ : 358.2535. Found: 358.2525.

Synthesis of 4-Butyl-4'-(O-allyl- $\beta$-hydroxyethyl)triphenylamine in One-Pot from Aniline, 1-Bromo-4-butylbenzene, and 1-Bromo-4-0-allyl- $\beta$-hydroxyethylbenzene. To a solution of $\mathrm{Pd}_{2}(\mathrm{dba})_{3}(0.285 \mathrm{~g}, 0.311 \mathrm{mmol})$ and DPPF $(0.259 \mathrm{~g}, 0.467 \mathrm{mmol})$ in toluene $(200 \mathrm{~mL})$ under nitrogen atmosphere was added 1-bromo-4-O-allyl- $\beta$-hydroxyethylben- zene (12.237 g, $50.747 \mathrm{mmol}$ ) at room temperature, and the resultant mixture was stirred at that temperature for $10 \mathrm{~min}$. Then, sodium tert-butoxide $(7.316 \mathrm{~g}, 76.121 \mathrm{mmol})$ and aniline $(4.962 \mathrm{~g}, 53.283 \mathrm{mmol})$ were added to this sol ution and stirred at $90{ }^{\circ} \mathrm{C}$ for $12 \mathrm{~h}$. At this time, the starting materials had disappeared as judged by TLC. To this solution was added sodium tert-butoxide $(6.340 \mathrm{~g}, 65.971 \mathrm{mmol})$ followed by a solution of $\mathrm{Pd}_{2}(\mathrm{dba})_{3}(0.558 \mathrm{~g}, 0.609 \mathrm{mmol})$, DPPF $(0.506 \mathrm{~g}$, $0.914 \mathrm{mmol})$, and 1-bromo-4-butyl benzene in toluene (100 $\mathrm{mL})$. The resulting solution was stirred at $90{ }^{\circ} \mathrm{C}$ for $24 \mathrm{~h}$. Following the standard workup procedure, purification of the reaction mixture by flash column chromatography using $10 \%$ ethyl acetate in hexane afforded $14.0 \mathrm{~g} \mathrm{(72 \% )}$ of the product as an yellow oil. ${ }^{1} \mathrm{H} N M R\left(\mathrm{C}_{6} \mathrm{D}_{6}, 300 \mathrm{MHz}\right) \delta 7.11$ (bt, $\left.6 \mathrm{H}\right)$; $7.04(\mathrm{~d}, 2 \mathrm{H}, \mathrm{J}=7.4 \mathrm{~Hz}) ; 7.00(\mathrm{~d}, 2 \mathrm{H}, \mathrm{J}=5.8 \mathrm{~Hz}) ; 6.93(\mathrm{t}, 2 \mathrm{H}$, $\mathrm{J}=5.1 \mathrm{~Hz}, \mathrm{~J}=8.3 \mathrm{~Hz}) ; 6.81(\mathrm{t}, 1 \mathrm{H}, \mathrm{J}=7.2 \mathrm{~Hz}) ; 5.81(\mathrm{~m}, 1 \mathrm{H})$; $5.20(\mathrm{~d}$ of $\mathrm{d}, 1 \mathrm{H}, \mathrm{J}=1.6 \mathrm{~Hz}, \mathrm{~J}=17.2 \mathrm{~Hz}) ; 5.01(\mathrm{~d}, 1 \mathrm{H}, \mathrm{J}=$ $10.4 \mathrm{~Hz}) ; 3.74(\mathrm{~d}, 2 \mathrm{H}, \mathrm{J}=5.2 \mathrm{~Hz}) ; 3.42(\mathrm{t}, 2 \mathrm{H}, \mathrm{J}=7.0 \mathrm{~Hz}$ ); $1.25(\mathrm{~m}, 2 \mathrm{H}) ; 0.84(\mathrm{t}, 3 \mathrm{H}, \mathrm{J}=7.3 \mathrm{~Hz}) .{ }^{13} \mathrm{C} \mathrm{NMR}\left(\mathrm{CD}_{2} \mathrm{Cl}_{2}, 75\right.$ $\mathrm{MHz}) \delta 148.6,146.5,145.8,138.1,135.6,133.9,130.0,129.5$, $129.4,124.8,124.3,123.5,122.3,116.5,72.0,71.5,36.0,35.4$, 34.1, 22.8, 14.1. FAB HRMS calcd for $\mathrm{C}_{27} \mathrm{H}_{31} \mathrm{NO}$ : 385.2406 . Found: 385.2414 .

Synthesis of 4-Butyl-4-(O-allyl- $\beta$-hydroxyethyl)triphenylamine in Two Steps from Aniline, 1-Bromo-4-0allyl- $\beta$-hydroxyethylbenzene, and 1-Bromo-4-butylbenzene. To a solution of $\mathrm{Pd}_{2}(\mathrm{dba})_{3}(0.570 \mathrm{~g}, 0.622 \mathrm{mmol})$ and DPPF $(0.518 \mathrm{~g}, 0.934 \mathrm{mmol})$ in toluene $(300 \mathrm{~mL})$ under nitrogen atmosphere was added 1-bromo-4-O-allyl- $\beta$-hydroxyethyl benzene $(24.574 \mathrm{~g}, 101.458 \mathrm{mmol})$ at room temperature, and the resultant mixture was stirred at that temperature for $10 \mathrm{~min}$. Then, sodium tert-butoxide (14.632 g, $152.242 \mathrm{mmol}$ ) and aniline ( $9.834 \mathrm{~g}, 106.566 \mathrm{mmol})$ were added to this solution and stirred at $90^{\circ} \mathrm{C}$ for $12 \mathrm{~h}$. Following the standard workup procedure, purification of the reaction mixture using $20 \%$ ethyl acetate in hexane afforded $24.9 \mathrm{~g}(97 \%)$ of 4 -(O-allyl- $\beta$ hydroxyethyl)diphenylamine as an yellow oil. ${ }^{1} \mathrm{H}$ NMR (acetone $\left.\mathrm{d}_{6}, 300 \mathrm{MHz}\right) \delta 7.37-7.09(\mathrm{~m}, 8 \mathrm{H}) ; 6.85(\mathrm{t}, 1 \mathrm{H}, \mathrm{J}=8.8 \mathrm{~Hz})$; $5.94(\mathrm{~m}, 1 \mathrm{H}) ; 5.25(\mathrm{~d}$ of $\mathrm{d}, 2 \mathrm{H}, \mathrm{J}=17.3 \mathrm{~Hz}, \mathrm{~J}=1.7 \mathrm{~Hz}) ; 5.13$ $(\mathrm{d}, 1 \mathrm{H}, \mathrm{J}=10.4 \mathrm{~Hz}) ; 4.00(\mathrm{~d}, 2 \mathrm{H}, \mathrm{J}=5.2 \mathrm{~Hz}) ; 3.62(\mathrm{t}, 2 \mathrm{H}, \mathrm{J}=$ $7.0 \mathrm{~Hz}$ ); $2.83\left(\mathrm{t}, 2 \mathrm{H}, \mathrm{J}=7.0 \mathrm{~Hz}\right.$ ). ${ }^{13} \mathrm{C} \mathrm{NMR}$ (acetone- $\mathrm{d}_{6}, 75$ $\mathrm{MHz}) \delta 144.9,142.4,136.2,131.9,130.4,129.8,120.4,118.4$, 117.3, 116.1. FAB HRMS calcd for $\mathrm{C}_{17} \mathrm{H}_{19} \mathrm{NO}$ : 253.1467 . Found: 253.1466.

To a solution of $\mathrm{Pd}_{2}(\mathrm{dba})_{3}(1.586 \mathrm{~g}, 1.733 \mathrm{mmol})$ and DPPF $(1.441 \mathrm{~g}, 2.600 \mathrm{mmol})$ in toluene $(300 \mathrm{~mL})$ under nitrogen atmosphere was added 1-bromo-4-butylbenzene $(29.536 \mathrm{~g}$, $138.600 \mathrm{mmol}$ ) at room temperature, and the resultant mixture was stirred at that temperature for $10 \mathrm{~min}$. Then, sodium tertbutoxide (16.650 g, $173.300 \mathrm{mmol})$ and 4-(O-allyl- $\beta$-hydroxyethyl)diphenylamine $(29.260 \mathrm{~g}, 115.500 \mathrm{mmol})$ were added to this solution and stirred at $90{ }^{\circ} \mathrm{C}$ for $24 \mathrm{~h}$. Following the standard workup procedure, purification of the reaction mixture using $10 \%$ ethyl acetate in hexane afforded $28.1 \mathrm{~g}(63 \%)$ of 4-butyl-4'-(O-allyl- $\beta$-hydroxyethyl)triphenylamine as a yellow oil. 
Synthesis of 4,4'-Bis(m-fluorophenyl-m'-tolylamino)biphenyl by the Two-Step Procedure. To a solution of $\mathrm{Pd}_{2-}$ $(\mathrm{dba})_{3}(778 \mathrm{mg}, 0.85 \mathrm{mmol}$ ) and DPPF $(695 \mathrm{mg}, 1.25 \mathrm{mmol}$ ) in dry toluene $(250 \mathrm{~mL})$ under nitrogen was added 4,4'-dibromobiphenyl $(50.04 \mathrm{~g}, 160 \mathrm{mmol})$, and the resultant mixture was stirred at room temperature for $15 \mathrm{~min}$. Then, sodium tertbutoxide $(46.6 \mathrm{~g}, 485 \mathrm{mmol})$ and m-toluidine $(36.1 \mathrm{~mL}, 337$ $\mathrm{mmol}$ ) were added to this solution, and the reaction mixture was warmed to $100{ }^{\circ} \mathrm{C}$ for $20 \mathrm{~h}$, at which time the reaction appeared complete by TLC. The flask was cooled to $-35^{\circ} \mathrm{C}$; the resulting solids were collected on a frit and washed with water. The solids were dissolved in hot toluene; the hot solution was filtered through Celite to remove palladium residues and cooled to $-35^{\circ} \mathrm{C}$ to afford $4,4^{\prime}$-(m-tolylamino)biphenyl (39.2 g, $108 \mathrm{mmol}, 67 \%$ ) as white leaflets. Mp 160 ${ }^{\circ} \mathrm{C}$. ${ }^{1} \mathrm{H}$ NMR $\left(300 \mathrm{MHz}\right.$, acetone $\left.\mathrm{d}_{6}\right) 57.51(\mathrm{~d}, 4 \mathrm{H}, \mathrm{J}=8.6 \mathrm{~Hz})$, $7.39(\mathrm{~s}, 2 \mathrm{H}), 7.17(\mathrm{~d}, 4 \mathrm{H}, \mathrm{J}=8.6 \mathrm{~Hz}), 7.12(\mathrm{t}, 2 \mathrm{H}, \mathrm{J}=7.7 \mathrm{~Hz})$, $6.96(\mathrm{~s}, 2 \mathrm{H}), 6.94(\mathrm{~d}, 2 \mathrm{H}, \mathrm{J}=7.5 \mathrm{~Hz}), 6.68(\mathrm{~d}, 2 \mathrm{H}, \mathrm{J}=7.5 \mathrm{~Hz})$, $2.26(\mathrm{~s}, 6 \mathrm{H}) .{ }^{13} \mathrm{C} \mathrm{NMR}\left(75 \mathrm{MHz}\right.$, acetone- $\left.\mathrm{d}_{6}\right) \delta 144.5,143.3$, 139.5, 133.4, 129.8, 127.6, 121.8, 118.7, 118.7, 118.3, 115.2, 21.6. $F A B$ HRMS calcd for $\mathrm{C}_{26} \mathrm{H}_{24} \mathrm{~N}_{2}$ : 364.1939. Found: 364.1937.

To a solution of $\mathrm{Pd}_{2}(\mathrm{dba})_{3}$ (355 mg, $0.388 \mathrm{mmol}$ ) and DPPF (330 mg, $0.595 \mathrm{mmol})$ in dry toluene $(200 \mathrm{~mL}$ ) was added 1-bromo-3-fluorobenzene ( $5 \mathrm{~mL}, 46 \mathrm{mmol}$ ), and the resultant mixture was stirred for $15 \mathrm{~min}$ at room temperature. Then, sodium tert-butoxide $(5.80 \mathrm{~g}, 60.3 \mathrm{mmol})$ and 4,4'-bis $(\mathrm{m}$ tolylamino)biphenyl $(7.06 \mathrm{~g}, 19.4 \mathrm{mmol})$ were added to this solution, and the reaction mixture was warmed to $100{ }^{\circ} \mathrm{C}$ for $24 \mathrm{~h}$, at which time the reaction appeared complete by TLC. The reaction mixture was transferred to a separating funnel together with water $(500 \mathrm{~mL})$ and ether $(500 \mathrm{~mL})$. The aqueous layer was extracted with ether until the extracts showed almost no fluorescence under a UV lamp. The combined organics were dried over magnesium sulfate and filtered through a bed of Celite. The solvents were removed from the filtrate under reduced pressure to give an oil that slowly solidified under vacuum. The material was dissolved in benzene and passed through a short column of silica gel, eluting with more benzene; after removal of the benzene a yell ow solid was obtained and found to be NMR-pure 4,4'-bis(m-fluorophenyl-m-tolylamino)biphenyl (9.78 g, $17.6 \mathrm{mmol}$, 92\%). The yield over two steps was, therefore, 62\%. Mp 139 ${ }^{\circ} \mathrm{C}$. ${ }^{1} \mathrm{H}$ NMR $\left(300 \mathrm{MHz}\right.$, acetone- $\left.\mathrm{d}_{6}\right) 57.57(\mathrm{~d}, 4 \mathrm{H}, \mathrm{J}=8.5 \mathrm{~Hz})$, $7.21(\mathrm{~m}, 4 \mathrm{H}), 7.10(\mathrm{~d}, 4 \mathrm{H}, \mathrm{J}=8.5 \mathrm{~Hz}), 6.96-6.68(\mathrm{~m}, 12 \mathrm{H}), 2.25$ $(\mathrm{s}, 6 \mathrm{H}) .{ }^{13} \mathrm{C}$ NMR $\left(75 \mathrm{MHz}\right.$, acetone-d $\left.\mathrm{d}_{6}\right) \delta 164.2(\mathrm{~d}, \mathrm{~J}=243.7$ $\mathrm{Hz}), 150.6(\mathrm{~d}, \mathrm{~J}=10.1 \mathrm{~Hz}), 147.8,147.2,140.3,136.1,131.4$ $(d, J=9.7 \mathrm{~Hz}), 130.3,128.3,126.7,125.9,125.6,123.4,119.0$, $109.8(\mathrm{~d}, \mathrm{~J}=24.4 \mathrm{~Hz}), 109.2(\mathrm{~d}, \mathrm{~J}=21.3 \mathrm{~Hz}), 21.3$. FAB HRMS calcd for $\mathrm{C}_{38} \mathrm{H}_{30} \mathrm{~F}_{2} \mathrm{~N}_{2}$ : 552.2377. Found: 552.2381. Anal. Calcd for $\mathrm{C}_{38} \mathrm{H}_{30} \mathrm{~F}_{2} \mathrm{~N}_{2}$ : C, 82.58; $\mathrm{H}, 5.47 ; \mathrm{N}, 5.07$. Found: C, 82.50; $\mathrm{H}, 5.52 ; \mathrm{N}, 5.00$.

Standard Procedure for the One-Pot Synthesis of 4,4Bis(diarylamino)biphenyl Compounds 10a-10k. To a solution of $\mathrm{Pd}_{2}(\mathrm{dba})_{3}$ (1.5 mol \% relative to the arylamine) and DPPF (2.25 mol \% relative to the arylamine) in toluene (200$300 \mathrm{~mL}$ ) under nitrogen atmosphere was added 4.4'-di bromobiphenyl ( 0.5 equiv relative to the arylamine) at room temperature, and the resultant mixture was stirred at that temperature for $10 \mathrm{~min}$. Then, sodium tert-butoxide (1.3 equiv relative to the arylamine) and arylamine (50-100 mmol) were added to this solution and stirred at $90^{\circ} \mathrm{C}$ for $4-5 \mathrm{~h}$. At this time, the starting materials had disappeared as judged by TLC. To this solution was added an additional amount of sodium tert-butoxide (1.3 equiv relative to the arylamine) followed by the second aryl bromide and toluene (100-200 mL). The resultant reaction mixture was monitored for completion of the reaction or until no further improvement in the reaction was noticed over time. Following the standard workup procedure, purification of the reaction mixture was performed by flash column chromatography by using toluene, toluene/ hexane mixtures, or ethyl acetate/hexane mixtures as the mobile phase to afford the 4,4'-bis(diarylamino)bi phenyl product.

4,4'-Bis(p-fluorophenyl-m'-tolylamino)biphenyl. Mp 62 ${ }^{\circ} \mathrm{C}$. ${ }^{1} \mathrm{H}$ NMR (acetone- $\left.\mathrm{d}_{6}, 300 \mathrm{MHz}\right) \delta 7.56(\mathrm{~d}, 4 \mathrm{H}, \mathrm{J}=8.5 \mathrm{~Hz})$; $7.21(\mathrm{t}, 2 \mathrm{H}, \mathrm{J}=7.6 \mathrm{~Hz}) ; 7.13(\mathrm{bt}, 8 \mathrm{H}) ; 7.07(\mathrm{~d}, 4 \mathrm{H}, \mathrm{J}=8.6$ $\mathrm{Hz}) ; 6.9$ (bt, 6H); $2.27(\mathrm{~s}, 6 \mathrm{H}) .{ }^{13} \mathrm{C}$ NMR (acetone- $\left.\mathrm{d}_{6}, 75 \mathrm{MHz}\right)$ $\delta$ 161.2, 158.0, 148.4, 147.7, 144.8, 139.9, 134.9, 130.0, 127.9, $127.3,127.2,125.3,124.6,124.0,121.9,116.9,116.6,21.4 . \mathrm{FAB}$ HRMS calcd for $\mathrm{C}_{38} \mathrm{H}_{31} \mathrm{~N}_{2} \mathrm{~F}_{2}(\mathrm{M}+\mathrm{H})$ : 553.2455. Found: 553.2442. Anal. Calcd for $\mathrm{C}_{38} \mathrm{H}_{30} \mathrm{~N}_{2} \mathrm{~F}_{2}$ : $\mathrm{C}, 82.58 ; \mathrm{H}, 5.47 ; \mathrm{N}$, 5.07. Found: $\mathrm{C}, 82.51 ; \mathrm{H}, 5.51 ; \mathrm{N}, 5.02$.

4,4'-Bis(m,m-difluorophenyl-m'-tolylamino)biphenyl. $\mathrm{Mp} 197^{\circ} \mathrm{C}$. ${ }^{1} \mathrm{H}$ NMR $\left(\mathrm{C}_{6} \mathrm{D}_{6}, 300 \mathrm{MHz}\right) \delta 7.51(\mathrm{~d}, 4 \mathrm{H}, \mathrm{J}=8.4$ $\mathrm{Hz}) ; 7.39(\mathrm{~s}, 2 \mathrm{H}) ; 7.25(\mathrm{~d}, 4 \mathrm{H}, \mathrm{J}=8.5 \mathrm{~Hz}) ; 7.19(\mathrm{~d}, 2 \mathrm{H}, \mathrm{J}=7.7$ $\mathrm{Hz}) ; 7.07(\mathrm{~d}, 2 \mathrm{H}, \mathrm{J}=7.9 \mathrm{~Hz}) ; 6.96(\mathrm{~d}, 2 \mathrm{H}, \mathrm{J}=7.4 \mathrm{~Hz}) ; 6.85(\mathrm{~d}$, $4 \mathrm{H}, \mathrm{J}=7.6 \mathrm{~Hz}) ; 6.47(\mathrm{t}, 2 \mathrm{H}, \mathrm{J}=8.6 \mathrm{~Hz}) ; 2.18(\mathrm{~s}, 6 \mathrm{H}) .{ }^{13} \mathrm{C}$ NMR $\left(\mathrm{C}_{6} \mathrm{D}_{6}, 75 \mathrm{MHz}\right) \delta 165.0-162.0$ (d of d, J $=245.5 \mathrm{~Hz}$; J $=15.0 \mathrm{~Hz}), 151.0(\mathrm{t}, \mathrm{J}=12.4 \mathrm{~Hz}), 146.7,146.1,139.9,136.5$, $129.9,128.2,126.9,126.0,125.7,123.5,104.5(\mathrm{~d}, \mathrm{~J}=17.6 \mathrm{~Hz})$, $96.7(\mathrm{t}, \mathrm{J}=25.4 \mathrm{~Hz}), 21.2$. FAB HRMS calcd for $\mathrm{C}_{38} \mathrm{H}_{29} \mathrm{~N}_{2} \mathrm{~F}_{4}$ $(\mathrm{M}+\mathrm{H})$ : 589.2267. Found: 589.2276. Anal. Calcd for $\mathrm{C}_{38} \mathrm{H}_{29} \mathrm{~N}_{2} \mathrm{~F}_{4}$ : C, 77.54; $\mathrm{H}, 4.79 ; \mathrm{N}, 4.76$. Found: $\mathrm{C}, 77.27 ; \mathrm{H}$, 4.89; N, 4.73 .

4,4'-Bis(m,m,p-trifluorophenyl-m'-tolylamino)biphenyl. Mp $213^{\circ} \mathrm{C}$. ${ }^{1} \mathrm{H}$ NMR $\left(\mathrm{C}_{6} \mathrm{D}_{6}, 300 \mathrm{MHz}\right) \delta 7.33(\mathrm{~d}, 4 \mathrm{H}, \mathrm{J}=$ $8.5 \mathrm{~Hz}) ; 6.98(\mathrm{~m}, 6 \mathrm{H}) ; 6.86(\mathrm{~s}, 2 \mathrm{H}) ; 6.77(\mathrm{~d}, 2 \mathrm{H}, \mathrm{J}=8.4 \mathrm{~Hz})$; $6.73(\mathrm{~d}, 2 \mathrm{H}, \mathrm{J}=7.6 \mathrm{~Hz}) ; 6.51(\mathrm{~d}, 2 \mathrm{H}, \mathrm{J}=6.1 \mathrm{~Hz}) ; 6.48(\mathrm{~d}, 2 \mathrm{H}$, $\mathrm{J}=6.0 \mathrm{~Hz}) ; 1.98(\mathrm{~s}, 6 \mathrm{H}) .{ }^{13} \mathrm{C} \mathrm{NMR}\left(\left(\mathrm{C}_{6} \mathrm{D}_{6}, 75 \mathrm{MHz}\right) \delta 153.7-\right.$ 150.2 ( $\mathrm{d}$ of $\mathrm{d}$ of $\mathrm{d}$, $\mathrm{J}=247.5 \mathrm{~Hz}$; J $=8.4 \mathrm{~Hz}$; J $=6.0 \mathrm{~Hz}$ ), 146.7, $146.2,144.0(\mathrm{~d}$ of $\mathrm{t}, \mathrm{J}=10.6 \mathrm{~Hz}$; J $=3.0 \mathrm{~Hz}$ ), 139.9, 137.5$133.8(\mathrm{~d}$ of $\mathrm{t}, \mathrm{J}=246.0 \mathrm{~Hz}$; $\mathrm{J}=15.9 \mathrm{~Hz}), 136.2,129.9,128.1$, $126.3,125.7,125.0,122.9,106.7(\mathrm{~d}$ of $\mathrm{d}, \mathrm{J}=15.9 \mathrm{~Hz}$; J $=6.8$ $\mathrm{Hz}$ ). FAB HRMS calcd for $\mathrm{C}_{38} \mathrm{H}_{27} \mathrm{~N}_{2} \mathrm{~F}_{6}(\mathrm{M}+\mathrm{H})$ : 625.2078; Found: 625.2079. Anal. Calcd for $\mathrm{C}_{38} \mathrm{H}_{26} \mathrm{~N}_{2} \mathrm{~F}_{6}$ : C, 73.07; $\mathrm{H}$, 4.20; N, 4.48. Found: C, 72.99; $H, 4.20 ; N, 4.41$.

4,4'-Bis(m-methoxyphenyl-m'-tolylamino)biphenyl. Mp $75{ }^{\circ} \mathrm{C} .{ }^{1} \mathrm{H}$ NMR (acetone- $\left.\mathrm{d}_{6}, 300 \mathrm{MHz}\right) \delta 7.56(\mathrm{~d}, 4 \mathrm{H}, \mathrm{J}=8.6$ $\mathrm{Hz}) ; 7.17(\mathrm{t}, 4 \mathrm{H}, \mathrm{J}=8.0 \mathrm{~Hz}, \mathrm{~J}=7.6 \mathrm{~Hz}) ; 7.07(\mathrm{~d}, 4 \mathrm{H}, \mathrm{J}=8.6$ $\mathrm{Hz}) ; 6.88(\mathrm{t}, 6 \mathrm{H}, \mathrm{j}=7.8 \mathrm{~Hz}, \mathrm{~J}=8.5 \mathrm{~Hz}) ; 6.63(\mathrm{bt}, 6 \mathrm{H}) ; 3.70(\mathrm{~s}$, $6 \mathrm{H}) ; 2.25(\mathrm{~s}, 6 \mathrm{H}) .{ }^{13} \mathrm{C}$ NMR (acetone- $\left.\mathrm{d}_{6}, 75 \mathrm{MHz}\right) \delta 161.5$, $149.8,148.4,147.6,139.9,135.3,130.8,130.0,127.9,126.0$, 124.9, 124.8, 122.7, 117.1, 110.7, 108.8, 55.4, 21.3. HRMS calcd for $\mathrm{C}_{40} \mathrm{H}_{37} \mathrm{~N}_{2} \mathrm{O}_{2}(\mathrm{M}+\mathrm{H})$ : 577.2855 . Found: 577.2844 . Anal. Calcd for $\mathrm{C}_{40} \mathrm{H}_{36} \mathrm{~N}_{2} \mathrm{O}_{2}$ : C, 83.30; $\mathrm{H}, 6.29 ; \mathrm{N}, 4.86$. Found: $\mathrm{C}, 83.12 ; \mathrm{H}, 6.36 ; \mathrm{N}, 4.75$.

4,4'-Bis(p-methoxyphenyl-m'-tolylamino)biphenyl. Mp $147^{\circ} \mathrm{C}^{1} \mathrm{H}$ NMR $\left(300 \mathrm{MHz}\right.$, acetone- $\left.\mathrm{d}_{6}\right) \delta 7.49(\mathrm{~d}, 4 \mathrm{H}, \mathrm{J}=8.4$ $\mathrm{Hz}), 7.14(\mathrm{t}, 2 \mathrm{H}, \mathrm{J}=5.5 \mathrm{~Hz}), 7.05(\mathrm{~d}, 4 \mathrm{H}, \mathrm{J}=9.1 \mathrm{~Hz}), 6.99(\mathrm{~d}$, $4 \mathrm{H}, \mathrm{J}=8.6 \mathrm{~Hz}), 6.92(\mathrm{~d}, 4 \mathrm{H}, \mathrm{J}=8.8 \mathrm{~Hz}), 6.86(\mathrm{br} \mathrm{s}, 2 \mathrm{H}), 6.83-$ $6.81(\mathrm{br} \mathrm{m}, 6 \mathrm{H}), 3.79(\mathrm{~s}, 6 \mathrm{H}), 2.22(\mathrm{~s}, 6 \mathrm{H}) ;{ }^{13} \mathrm{C} \mathrm{NMR}(75 \mathrm{MHz}$, dichloromethane- $\mathrm{d}_{2}$ ) $\delta 156.7,148.3,147.5,141.0,139.4,134.0$, $129.3,127.7,127.3,124.2,123.3,123.0,120.7,115.0,55.9,21.7$. EI HRMS calcd for $\mathrm{C}_{40} \mathrm{H}_{36} \mathrm{~N}_{2} \mathrm{O}_{2}$ : 576.2777. Found: 576.2769 . Anal. Calcd for $\mathrm{C}_{40} \mathrm{H}_{36} \mathrm{~N}_{2} \mathrm{O}_{2}$ : C, 83.30; $\mathrm{H}, 6.29 ; \mathrm{N}, 4.86$. Found: C, 83.39; $\mathrm{H}, 6.33$; N, 4.76.

4,4'-Bis(m-(trifluoromethyl)phenyl-m'-tolylamino)biphenyl. Mp $156{ }^{\circ} \mathrm{C}$. ${ }^{1} \mathrm{H}$ NMR $(300 \mathrm{MHz}$, acetone-d 6 ) $\delta 7.64$ $(\mathrm{d}, \mathrm{J}=8.5 \mathrm{~Hz}, 4 \mathrm{H}), 7.47(\mathrm{t}, \mathrm{J}=8.2 \mathrm{~Hz}, 2 \mathrm{H}), 7.25(\mathrm{~m}, 8 \mathrm{H})$, $7.15(\mathrm{~d}, \mathrm{~J}=8.5 \mathrm{~Hz}, 4 \mathrm{H}), 6.97(\mathrm{~m}, 6 \mathrm{H}), 2.27(\mathrm{~s}, 6 \mathrm{H}) ;{ }^{13} \mathrm{C} N M R$ (75 $\mathrm{MHz}$, acetone-d $\mathrm{d}_{6}$ ) $\delta 149.5,147.7,147.0,140.5,136.3,131.8$ $(q, J=31.7 \mathrm{~Hz}), 131.1,130.5,128.4,126.8,126.5,126.1,125.7$, $122.3(\mathrm{q}, \mathrm{J}=142.8 \mathrm{~Hz}), 119.4(\mathrm{q}, \mathrm{J}=3.7 \mathrm{~Hz}), 118.9(\mathrm{q}, \mathrm{J}=$ 3.6 Hz), 21.3. FAB HRMS calcd for $\mathrm{C}_{40} \mathrm{H}_{30} \mathrm{~F}_{6} \mathrm{~N}_{2}: 652.2313$. Found: 652.2323. Anal. Calcd for $\mathrm{C}_{40} \mathrm{H}_{30} \mathrm{~F}_{6} \mathrm{~N}_{2}: \mathrm{C}, 73.61 ; \mathrm{H}$, 4.63; N, 4.29. Found: C, 73.76; $H, 4.72 ; N, 4.21$.

4,4'-Bis(m-cyanophenyl-m'-tolylamino)biphenyl. Mp $72{ }^{\circ} \mathrm{C}$ (broad melting range). ${ }^{1} \mathrm{H} N M R\left(300 \mathrm{MHz}\right.$, acetone- $\left.\mathrm{d}_{6}\right)$ $\delta 7.62(\mathrm{~d}, 4 \mathrm{H}, \mathrm{J}=8.3 \mathrm{~Hz}), 7.55(\mathrm{~m}, 2 \mathrm{H}), 7.41(\mathrm{t}, 2 \mathrm{H}, \mathrm{J}=8.6$ $\mathrm{Hz}), 7.32-7.22(\mathrm{~m}, 6 \mathrm{H}), 7.15(\mathrm{~d}, 4 \mathrm{H}, \mathrm{J}=8.5 \mathrm{~Hz}), 7.01-6.92$ (br m, 6H), $2.27(\mathrm{~s}, 6 \mathrm{H}) .{ }^{13} \mathrm{C} N M R\left(75 \mathrm{MHz}\right.$, acetone- $\left.\mathrm{d}_{6}\right) \delta$ $149.3,147.0,146.4,140.3,136.2,132.0,120.2,128.2,126.7$, $126.1,125.5,125.3,125.0,124.5,123.3,118.9,113.6,21.1 . \mathrm{EI}$ HRMS calcd for $\mathrm{C}_{40} \mathrm{H}_{30} \mathrm{~N}_{4}$ : 566.2470. Found: 566.2471. Anal. Calcd for $\mathrm{C}_{40} \mathrm{H}_{30} \mathrm{~N}_{4}$ : C, 84.78; $\mathrm{H}, 5.34 ; \mathrm{N}, 9.89$. Found: $\mathrm{C}$, 84.24; $\mathrm{H}, 5.34 ; \mathrm{N}, 9.47$.

4,4'-Bis(p-cyanophenyl-m'-tolylamino)biphenyl. Mp 90 ${ }^{\circ} \mathrm{C}$. ${ }^{1} \mathrm{H}$ NMR $\left(300 \mathrm{MHz}\right.$, acetone- $\left.\mathrm{d}_{6}\right) \delta 7.67(\mathrm{~d}, 4 \mathrm{H}, \mathrm{J}=8.5 \mathrm{~Hz})$, $7.53(\mathrm{~d}, 4 \mathrm{H}, \mathrm{J}=8.9 \mathrm{~Hz}), 7.30(\mathrm{t}, 2 \mathrm{H}, \mathrm{J}=8.0 \mathrm{~Hz}), 7.23(\mathrm{~d}, 4 \mathrm{H}$, $\mathrm{J}=8.5 \mathrm{~Hz}), 7.08-7.06(\mathrm{br} \mathrm{m}, 4 \mathrm{H}), 7.02(\mathrm{br} \mathrm{s}, 2 \mathrm{H}), 6.98(\mathrm{~d}, 4 \mathrm{H}$, $\mathrm{J}=8.7 \mathrm{~Hz}), 2.29(\mathrm{~s}, 6 \mathrm{H}) ;{ }^{13} \mathrm{C} \mathrm{NMR}\left(75 \mathrm{MHz}\right.$, acetone- $\left.\mathrm{d}_{6}\right) \delta$ 
$152.1,146.4,145.9,140.5,137.0,133.7,130.4,128.4,127.7$, $126.9,126.7,124.3,120.1,120.0,103.0,21.0$. FAB HRMS calcd for $\mathrm{C}_{40} \mathrm{H}_{30} \mathrm{~N}_{4}$ : 566.2470. Found 566.2499.

4,4'-Bis(1-naphthyl-m-tolylamino)biphenyl. Mp $221^{\circ} \mathrm{C}$. ${ }^{1} \mathrm{H}$ NMR $\left(\mathrm{C}_{6} \mathrm{D}_{6}, 300 \mathrm{MHz}\right) \delta 8.21(\mathrm{~d}, 2 \mathrm{H}, \mathrm{J}=8.2 \mathrm{~Hz}) ; 7.63(\mathrm{~d}$, $2 \mathrm{H}, \mathrm{J}=7.8 \mathrm{~Hz}) ; 7.52(\mathrm{~d}, 2 \mathrm{H}, \mathrm{J}=7.9 \mathrm{~Hz}) ; 7.28(\mathrm{~d}, 4 \mathrm{H}$, J $=8.3$ $\mathrm{Hz}) ; 7.24-6.94(\mathrm{~m}, 18 \mathrm{H}) ; 6.65(\mathrm{~d}, 2 \mathrm{H}$, J $=6.6 \mathrm{~Hz}) ; 1.93(\mathrm{~s}, 6 \mathrm{H})$. ${ }^{13} \mathrm{C}$ NMR $\left(\mathrm{CD}_{2} \mathrm{C}_{12}, 75 \mathrm{MHz}\right) \delta 148.9,148.0,144.0,139.6,135.9$, 134.0, 131.9, 129.4, 128.9, 127.8, 127.4, 127.0, 126.9, 126.8, $126.7,124.7,123.4,123.3,122.2,119.9,21.7$. FAB HRMS calcd for $\mathrm{C}_{46} \mathrm{H}_{36} \mathrm{~N}_{2}$ : 616.2879. Found: 616.2851. Anal. Calcd for $\mathrm{C}_{46} \mathrm{H}_{36} \mathrm{~N}_{2}$ : C, 89.58; $\mathrm{H}, 5.88 ; \mathrm{N}, 4.54$. Found: C, 89.64; $\mathrm{H}, 5.89$; $\mathrm{N}, 4.49$.

4,4'-Bis(1-naphthyl-p-fluorophenylamino)biphenyl. Mp $230^{\circ} \mathrm{C}$. ${ }^{1} \mathrm{H}$ NMR (acetone- $\left.\mathrm{d}_{6}, 300 \mathrm{MHz}\right) \delta 7.97(\mathrm{t}, 4 \mathrm{H}, \mathrm{J}=8.2$ $\mathrm{Hz}) ; 7.88(\mathrm{~d}, 2 \mathrm{H}, \mathrm{J}=8.2 \mathrm{~Hz}) ; 7.58-7.35(\mathrm{~m}, 12 \mathrm{H}) ; 7.08-7.00$ $(\mathrm{bm}, 8 \mathrm{H}) ; 6.93(\mathrm{~d}, 4 \mathrm{H}, \mathrm{J}=8.6 \mathrm{~Hz}) .{ }^{13} \mathrm{C} \mathrm{NMR}\left(\mathrm{CD}_{2} \mathrm{Cl}_{2}, 75 \mathrm{MHz}\right)$ $\delta 160.2-157.0(\mathrm{~d}, \mathrm{~J}=241.4 \mathrm{~Hz}), 147.9,144.8,143.7,135.7$, 133.7, 131.4, 128.8, 127.7, 127.4, 127.3, 126.9, 126.7, 126.6, $124.5(\mathrm{~d}, \mathrm{~J}=8.0 \mathrm{~Hz}), 124.3,121.4,116.1(\mathrm{~d}, \mathrm{~J}=22.7 \mathrm{~Hz})$. FAB HRMS calcd for $\mathrm{C}_{44} \mathrm{H}_{30} \mathrm{~N}_{2}: 624.2377$. Found: 624.2365. Anal. Calcd for $\mathrm{C}_{44} \mathrm{H}_{30} \mathrm{~N}_{2}$ : C, 84.59; $\mathrm{H}, 4.84 ; \mathrm{N}, 4.48$. Found: C, 84.64; H, 4.92; N, 4.41.
Acknowledgment. The work in this paper was performed in part at the Center for Space Microelectronics Technology, J et Propulsion Laboratory (J PL), California Institute of Technology under contract with the National Aeronautics and Space Administration (NASA). The work was sponsored by the Ballistic Missile Defense Organization, Innovative Science and Technology Office. In addition the work was supported by the U.S. Office of Naval Research (ONR) through the MURI Center for Advanced Multifunctional Nonlinear Optical Polymers and Molecular Assemblies (CAMP), the U.S. National Science Foundation (NSF), a MRSEC of theNational Science Foundation (DMR-94-00362), and the USAF Office of Scientific Research (AFOSR). We thank Professor N. R. Armstrong (University of Arizona) for valuable discussions.

CM970567N 